\title{
Nursing Research
}

National Cancer Institute

\section{Source}

National Cancer Institute. Nursing Research. NCI Thesaurus. Code C15285.

Clinical research carried out by nurses. 